СЕКСУАЛНО ПОНАШАҢЕ СТУДЕНАТА И ПРОЦЕНА ЗНАЫА О ХИВ ИНФЕКЦИЈИ

Невенка Јањић ${ }^{1}$

\title{
SEXUAL BEHAVIOR OF STUDENTS AND ASSESSMENT OF KNOWLEDGE ABOUT HIV INFECTION
}

Nevenka Janjić

\section{Сажетак}

Циь истраживања је да се сагледају ставови и навике студената у вези са сексуалним понашањем. Студија пресека спроведена је у популацији студената Високе здравствене школе струковних студија у Београду, новембра 2011. године. Испитивани узорак чинило је 266 студената. Коришћен је анкетни упитник преузет из пројекта „Здравствено стање, здравствене потребе и коришћење здравствене заштите становништва Србије" из 2000. године, који је дизајниран од стране СЗО. Анкета садржи 15 питана, отворено-затвореног типа, са понућеним модалитетима одговора. База података је креирана у статистичком пакету SPSS 13.0. За статистичку обраду коришћен је $\chi^{2}$ тест. Резултати су приказани табеларно. Резултати нашег истраживања указују да су упркос високом нивоу знана о ХИВ инфекиији и мерама превенције од полно преносивих болести и ХИВ-а, недоследна употреба кондома и упуштане у ризична сексуална понашања главни обрасци сексуалног понашањ а у студентској популащији.

Кључне речи: студенти, сексуално понашағе, ХИВ инфекиија.

\section{Summary}

The aim of the research was to investigate the attitudes and habits of students related to sexual behavior. Cross-sectional study was carried out among the student population of the Medical College of Vocational Studies in Belgrade, in november 2011. Examined sample population consisted of 266 students. They used a questionnaire taken over from the Project called „State of Health and HealthCare Needs of Population in Serbia, and Its Use of HealthCare Protection Service" from the year 2000, designed by the WHO. Questionnaire consists of 15 questions, open-close type, with offered answers. Analysis was done in the SPSS 13.0 software package. The results of questionnaires are treated with $\chi^{2}$ test. Results are presented in tables. Our findings indicate that, despite the high level of knowledge about HIV infection and preventive measures against sexually transmitted diseases and HIV, inconsistent use of condoms and engaging in risky sexual contacts, are main forms of sexual behavior in the student population.

Key words: students, sexual behavior, HIV infection.

\footnotetext{
${ }^{1}$ Др Невенка Јањић, Дом здравља, Ариље (Health Centre, Arilje).
} 


\section{УВОД}

A

долесценцијајепериодсазревања, сазнавања, истраживања, успостављања нових односа са околином, стварања и потврде сопственог идентитета. У адолесценцији млади полно сазревају. Важно је да млади људи разумеју сопствено тело и начин на који функционише, да прихвате и стекну позитиван став о сопственој сексуалности, што им може помоћи да себе сагледају у позитивном светлу и да поштују себе као сексуално биће. ${ }^{(1)}$

Као веома вулнерабилна група, млади су подложни прихватању разних облика ризичног понашања, што повећава пријемчивост за бројне поремећаје здравља. ${ }^{(2)}$

Сексуално здравље је стање физичког, емоционалног, менталног и социјалног благостања у односу на сексуалност, а не само одсуство болести, дисфункције или слабости. ${ }^{(3)}$

Рано ступање у сексуалне односе, некоришћење кондома увек и при сваком сексуалном контакту са једним или више сексуалних патрнера, већи број сексуалних партнера, ступање у везе „за једно вече“, ступање у сексуалне односе под дејством алкохола и наркотика, представљају ризична сексуална понашања која могу имати дуготрајне, нежељене и тешке последице по здравље младих. ${ }^{(4,5,6)}$

Такође, млади су у већем ризику од бројних негативних последица које произилазе из сексуалних односа, јер немају довољно развијену свест о важности безбедног и одговорног сексуалног понашања. ${ }^{(7)}$

\section{ЦИљ}

Циљ истраживања је да се сагледају ставови и навике студената у вези са сексуалним понашањем и процена знања о ХИВ инфекцији.

\section{МЕТОДЕ}

Студија пресека спроведена је у популацији студената Високе здравствене школе струковних студија у Београду. Испитивани узорак чинило је 266 студената. Коришћен је анкетни упитник преузет из пројекта „Здравствено стање, здравствене потребе и коришћење здравствене заштите становништва Србије" из 2000. године, који је дизајниран од стране СЗО. Анкета садржи 15 питања, отворено-затвореног типа, са понуђеним модалитетима одговора. База података је креирана у статистичком пакету SPSS 13.0. За статистичку обраду коришћен je $\chi^{2}$ тест. Резултати су приказани табеларно.

\section{РЕЗУЛТАТИ}

Од укупног броја анкетираних испитаника, $77,3 \%$ су студенти женског пола. Сексуалне односе има 62,6\% испитаника, при чему статистички значајно више девојака $(\mathrm{p}<0,000)$. Сексуално искуство доживело је $61,2 \%$ студенткиња и $38,8 \%$ студената.

Разлог ступања у први сексуални однос код више од половине $(52,4 \%)$ испитаника је љубав према партнеру, док је 10,2\% њих као разлог навело страст, а 23,8\% физичку привлачност.

Највећи број испитаника $(78,1 \%)$ не ступа у сексуалне односе при првом сусрету са партнером, док то чини $6,2 \%$ испитаника. Понекад то учини 12,2\% анкетираних. Посматрано по полу, значајније више девојака ступа у сексуални однос при првом сусрету са партнером (63\%) у односу на младиће $(37 \%)(\mathrm{p}<0,000)$.

Више од половине $(55,4 \%)$ испитаника који имају сексуалне односе не користи контрацептивна средства, 28,3\% њих користи, $11,1 \%$ њих сматра да за то нема потребе, док $8,2 \%$ није одговорило на постављено питање. Нема статистички значајне разлике у учесталости коришћења контрацептивних средстава између студената мушког и женског пола ( $>0,05)$.

Доследна употреба кондома нађена је код нешто мање од половине испитаника $(43,7 \%)$. Ово контрацептивно средство понекад користи $38,1 \%$, а никада $18,6 \%$ студената. Постоји високо статистички значајна разлика у коришћењу кондома код 
мушких и женских студената $(\mathrm{p}<0,001)$. Већина студената (79\%) одржава сексуалне односе са једним партнером. Међу мушким испитаницима 3,5 пута је чешћи одговор да имају односе са два или више партнера него код женских испитаника, постоји високо статистички значајна разлика $(\mathrm{p}<0,000)$. Испитаници мушког пола 7 пута чешће ступају у сексуалне контакте са особом коју први пут срећу од испитаница женског пола. Постоји високо статистички значајна разлика између пола и ступања у сексуалне односе са непознатом особом $(\mathrm{p}<0,001)$. При првом сексуалном односу $82,1 \%$ испитаника захтева употребу кондома. Нема статистички значајне разлике по полу $(\mathrm{p}>0,05)$ (табела 1).

Табела 1. Сексуално понамање студената посматрано у односу на пол.

\begin{tabular}{|c|c|c|c|c|}
\hline \multicolumn{2}{|c|}{ Сексуално понашање студената } & \multicolumn{2}{|c|}{ ПОЛ } & \multirow{6}{*}{\begin{tabular}{|c}
$\begin{array}{c}\text { Статистичка } \\
\text { значајност } \\
\text { разлика }\end{array}$ \\
$\mathrm{p}<0,000$ \\
\end{tabular}} \\
\hline & & Мушки (\%) & Женски (\%) & \\
\hline \multirow{4}{*}{$\begin{array}{l}\text { Користи } \\
\text { презерватив }\end{array}$} & никад & 20,9 & 16,4 & \\
\hline & понекад & 31,0 & 45,2 & \\
\hline & увек & 48,1 & 39,4 & \\
\hline & укупно & 100 & 100 & \\
\hline \multirow{4}{*}{$\begin{array}{l}\text { Одржава } \\
\text { сексуалне односе } \\
\text { са }\end{array}$} & једним партнером & 66,0 & 92,1 & \multirow[t]{4}{*}{$\mathrm{p}<0,000$} \\
\hline & $\begin{array}{l}\text { два и више } \\
\text { партнера }\end{array}$ & 11,2 & 3,2 & \\
\hline & без одговора & 22,8 & 4,7 & \\
\hline & укупно & 100 & 100 & \\
\hline \multirow{4}{*}{$\begin{array}{l}\text { Ступа у сексуалне } \\
\text { односе при првом } \\
\text { контакту }\end{array}$} & не & 75,0 & 90,1 & \multirow[t]{4}{*}{$\mathrm{p}<0,000$} \\
\hline & да & 14,0 & 1,9 & \\
\hline & понекад & 11,0 & 8,0 & \\
\hline & укупно & 100 & 100 & \\
\hline \multirow{4}{*}{$\begin{array}{l}\text { При првом } \\
\text { сексуалном } \\
\text { контакту захтева } \\
\text { употребу кондома }\end{array}$} & не & 2,1 & 7,8 & \multirow[t]{4}{*}{$\mathrm{p}>0,05$} \\
\hline & да & 80,2 & 84,1 & \\
\hline & понекад & 17,7 & 8,1 & \\
\hline & укупно & 100 & 100 & \\
\hline
\end{tabular}

Да се инфекција ХИВ-ом може избећи сматра 92,3\% студената. На питање да ли се људи могу заштити од инфицирања ХИВ-ом ако имају само једног сексуалног партнера који није заражен и немају друге партнере, њих 77,6\% дало је потврдан одговор док се $1 / 5$ њих не слаже са овом тврдњом. Највећи проценат студената, 80\% њих, сматра да се људи могу заштитити од инфицирања ХИВ -ом правилном употребом кондома приликом сваког сексуалног односа. На питање да ли се људи могу заштитити од инфицирања ХИВом ако уопште немају сексуалне односе, $2 / 3$ је одговорило потврдно. Нешто више од половине испитаника (56,3\%) сматра да се сида не може добити уједом комарца. Висок проценат испитаника $(84,8 \%)$ сматра да особа која изгледа здрава може бити носилац вируса сиде. Највећи проценат $(78,8 \%)$ сматра да се сида може пренети са мајке на дете, као и са мајке на дете током трудноће $(77,6 \%)$. На питање да ли се вирус сиде може пренети са мајке на дете приликом порођаја, њих $72,3 \%$ је одговорило потврдно, док сваки 11. сматра да то није могуће. Нешто мање од половине студената $(45,9 \%)$ сматра да се вирус сиде може пренети са мајке на дете приликом дојења. Са тврдњом да и даље треба куповати храну код продаваца за кога сте сазнали да има сиду или вирус сиде слаже се $31,5 \%$, док је $1 / 3$ студената дало негативан одговор (табела 2). 
Табела 2. Знаға студената о ХИВ инфекиији и начинима преношења.

\begin{tabular}{|c|c|c|c|c|c|}
\hline $\begin{array}{c}\text { Знања студената о ХИВ инфекцији и начинима } \\
\text { преношења }\end{array}$ & $\begin{array}{l}\text { Да } \\
\%\end{array}$ & $\begin{array}{l}\mathrm{He} \\
\%\end{array}$ & $\begin{array}{c}\text { Не зна } \\
\%\end{array}$ & $\begin{array}{c}\text { Без } \\
\text { одговора } \\
\%\end{array}$ & $\begin{array}{l}\text { Укупно } \\
\%\end{array}$ \\
\hline Постоји начин да се избегне инфекција ХИВ-ом & 92,3 & 4,7 & $0,4 \%$ & 2,6 & 100 \\
\hline $\begin{array}{l}\text { Људи се могу заштитити од инфицирања ХИВ-ом } \\
\text { ако имају само једног сексуалног партнера који није } \\
\text { заражен и нема друге партнере }\end{array}$ & 77,6 & 19,3 & $8,2 \%$ & 4,9 & 100 \\
\hline $\begin{array}{l}\text { Људи се могу заштитити од инфицирања ХИВ-ом } \\
\text { правилном употребом кондома приликом сваког } \\
\text { сексуалног односа }\end{array}$ & 79,9 & 10,2 & 5,4 & 4,5 & 100 \\
\hline $\begin{array}{l}\text { Људи се могу заштитити од инфицирања ХИВ-ом } \\
\text { ако уопште немају сексуалне односе }\end{array}$ & 75,0 & 4,1 & 15,6 & 5,3 & 100 \\
\hline Сида се може добити уједом комарца & 17,9 & 56,3 & 21,3 & 4,5 & 100 \\
\hline $\begin{array}{l}\text { Особа која изгледа здрава може бити носилац } \\
\text { вируса сиде }\end{array}$ & 84,8 & 5,9 & 5,0 & 4,3 & 100 \\
\hline Вирус сиде се може пренети са мајке на дете & 78,8 & 9,9 & 5,9 & 5,4 & 100 \\
\hline $\begin{array}{l}\text { Вирус сиде се може пренети са мајке на дете током } \\
\text { трудноће }\end{array}$ & 77,6 & 8,0 & 10,0 & 4,4 & 100 \\
\hline $\begin{array}{l}\text { Вирус сиде се може пренети са мајке на дете } \\
\text { приликом порођаја }\end{array}$ & 72,3 & 8,8 & 12,7 & 6,2 & 100 \\
\hline $\begin{array}{l}\text { Вирус сиде се може пренети са мајке на дете преко } \\
\text { млека приликом дојења }\end{array}$ & 45,9 & 12,5 & 35,8 & 5,8 & 100 \\
\hline $\begin{array}{l}\text { Наставнику који има вирус, а још није оболео од } \\
\text { сиде, треба дозволити да и даље ради у школи }\end{array}$ & 39,7 & 25,4 & 29,3 & 5,6 & 100 \\
\hline $\begin{array}{l}\text { И даље треба куповати храну код продавца за кога } \\
\text { сте сазнали да има сиду или вирус сиде }\end{array}$ & 31,5 & 34,1 & 28,5 & 5,9 & 100 \\
\hline
\end{tabular}

\section{ДИСКУСИЈА}

Резултати нашег истраживања показују да сексуалне односе има $61,2 \%$ студенткиња и $38,8 \%$ студената, а као најчешћи разлог ступања у први сексуални однос наводе љубав према партнеру $(52,4 \%)$. У истраживању о „Регулацији фертилитета у адолесцентном узрасту“, добијени су слични резултати, где су најчешћи мотиви првог полног односа љубав $(32,8 \%)$, затим радозналост $(30,9 \%)$ и страст $(9,5 \%) .{ }^{(8)}$

Резултати истраживања, спроведених у САД, показују да се $41 \%$ младића и $13 \%$ девојака понаша промискуитетно, ступајући истовремено у везу са више партнера или мењајући партнере у низу, током кратког временског периода. ${ }^{(9)}$ У нашем истраживању више од две трећине сту- дената (79\%) одржава сексуалне односе са једним партнером, док мушки студенти 3,5 пута чешће имају односе са два или више партнера.

Испитивањем доследне употребе кондома на узорку америчких студената млађих од 25 година налази се да само једна трећина младих $(33,3 \%)$ доследно користи кондом, и то чешће мушкарци. ${ }^{(9)}$ И наше истраживање показује да је недоследна употреба кондома главни образац понашања у студентској популацији. Ово контрацептивно средство понекад користи $38,1 \%$, а никада $18,6 \%$ студената, док га увек при сексуалном односу користи тек нешто мање од половине студената (43,7\%).

Студенти нашег истраживања одлично познају пренос ХИВ инфекције сексуалним путем, као и начин заштите од оваквог пута 
преноса, док у нешто мањем проценту познају вертикалну трансмисију ХИВ инфекције. Међутим, бројне студије указују на то да висок ниво знања испитаника о ХИВ инфекцији и мерама превенције полно преносивих болести и ХИВ-а није спречио упуштања испитаника у ризична сексуална понашања. $^{(10)}$

\section{ЗАКЉУЧАК}

Студенти су показали висок ниво знања о ХИВ инфекцији и начинима на који се она преноси. Упркос знању, недоследна употреба кондома, као и упуштања у ризична сексуална понашања главни су обрасци сексуалног понашања у студентској популацији. Како би се спречиле бројне нежељене последице незнања и ризичног сексуалног понашања неопходно је континуирано спроводити информисање и едукацију младих о репродуктивном здрављу и безбедном сексуалном понашању.

\section{ЛИТЕРАТУРА}

1. Седлецки K, Понашағе и ставови адолесиената релевантни за репродуктивно здравље. Становништво 2001; 39:91-117.

2. Neutbeam D. Health promotion glossary. Health promotion international 1998; 4: 369-394.

3. UNAIDS: Report On The Global Aids Epidemic. Geneva. UNAIDS, 2006.

4. Илић Влатковић В, Сексуално понашағе и ризик за AIDS. Градски завод за заштиту здравља, Београд, 2005.

5. Кекуш Д, Здравствено васпитање. Ауторско издање, II издање, Београд, 2002.
6. Jackson C. Behavioural science theory and principles for practice in health education. Health Education Research 1997; 2(1): 143-150.

7. Marie St. Rose. African American college freshman students knowledge, attitudes, beliefs, and behavior related to HIV: A preliminary Investigation, 2008; 6(3): 540580.

8. Мијановић Д, Регулащија фертилитета у адолесцентном узрасту. Докторска дисертација. Нови Сад, Медицински факултет Универзитета у Новом Саду; 1995.

9. Bell TA, Hein K. Adolescents and Sexually Transmitted Diseases. In: K. Holmes, et al., eds. Sexually Transmitted Diseases. New York; 1990; 73-84.

Контакт: Др Невенка Јањић, Ул. Светолика Лазаревића 19, 31230 Ариље, тел. 063/7355970, e-mail: nevenkajanjic@gmail.com 